\title{
Deciphering the functional role of EGR1 in Prostaglandin F2 alpha induced luteal regression applying CRISPR in corpus luteum of buffalo
}

Meeti Punetha ${ }^{1 *} \mathbb{D}$, Sai Kumar ${ }^{1}$, Avishek Paul ${ }^{1}$, Bosco Jose ${ }^{1}$, Jaya Bharati ${ }^{2}$, Arvind Sonwane $^{3}$, Jonathan A. Green ${ }^{4}$, Kristin Whitworth ${ }^{4}$ and Mihir Sarkar ${ }^{1}$

\begin{abstract}
Background: PGF2a is essential for the induction of the corpus luteum regression which in turn reduces progesterone production. Early growth response (EGR) proteins are Cys2-His2-type zinc-finger transcription factor that are strongly linked to cellular proliferation, survival and apoptosis. Rapid elevation of EGR1 was observed after luteolytic dose of PGF2a. EGR1 is involved in the transactivation of many genes, including TGF $\beta 1$, which plays an important role during luteal regression.
\end{abstract}

Methods: The current study was conducted in buffalo luteal cells with the aim to better understand the role of EGR1 in transactivation of TGF $\beta 1$ during PGF2a induced luteal regression. Luteal cells from mid stage corpus luteum of buffalo were cultured and treated with different doses of PGF2a for different time durations. Relative expression of mRNAs encoding for enzymes within the progesterone biosynthetic pathway (3BHSD, CYP11A1 and StAR); Caspase 3; AKT were analyzed to confirm the occurrence of luteolytic event. To determine if EGR1 is involved in the PGF2a induced luteal regression via induction of TGF $\beta 1$ expression, we knocked out the EGR1 gene by using CRISPR/Cas9.

Result: The present experiment determined whether EGR1 protein expression in luteal cells was responsive to PGF2a treatment. Quantification of EGR1 and TGFB1 mRNA showed significant up regulation in luteal cells of buffalo at $12 \mathrm{~h}$ post PGF2 $\mathrm{a}$ induction. In order to validate the role of PGF2 $\mathrm{a}$ on stimulating the expression of TGF 1 by an EGR1 dependent mechanism we knocked out EGR1. The EGR1 ablated luteal cells were stimulated with PGF2 $a$ and it was observed that EGR1 KO did not modulate the PGF2a induced expression of TGF 1 1. In PGF2a treated EGR1 KO luteal cell, the mRNA expression of Caspase 3 was significantly increased compared to PGF2a treated wild type luteal cells maintained for $12 \mathrm{~h}$. We also studied the influence of EGR1 on steroidogenesis. The EGR1 KO luteal cells with PGF2a treatment showed no substantial difference either in the progesterone concentration or in StAR mRNA expression with PGF2a-treated wild type luteal cells.

Conclusion: These results suggest that EGR1 signaling is not the only factor which plays a role in the regulation of PGF2 $\alpha$ induced TGF $\beta 1$ signaling for luteolysis.

Keywords: Buffalo, Corpus luteum, EGR, CRISPR/Cas9, Luteolysis

*Correspondence: meetipunetha283@gmail.com

1 Physiology \& Climatology Division, ICAR-Indian Veterinary Research Institute, Izatnagar, Bareilly, Uttar Pradesh 243122, India

Full list of author information is available at the end of the article

\section{Background}

The corpus luteum is a transient endocrine organ which regulates ovarian cyclicity and maintains pregnancy by acting as the primary source of progesterone production 
(P4) in bovine and numerous domestic species. The development of the corpus luteum and its endocrine function are dependent on angiogenesis and vasculogenesis. The mature corpus luteum is comprised of two steroidogenic cell populations, the large and small luteal cells, which are derived from ruptured follicular granulosa and thecal cell, respectively [1]. These large and small luteal cells have ProstaglandinF2 $\alpha$ (PGF $2 \alpha$ ) receptors, which upon binding by PGF2 $\alpha$, can induce luteal regression [2]. Corpus luteum regression leads to a decline in circulating progesterone concentration, which promotes follicular growth and a resumption of reproductive cyclicity [3].

In bovine, PGF2 $\alpha$ stimulation of the ovary suppresses luteotropic factors and stimulates luteolytic factors [4]. Indeed, PGF $2 \alpha$ is the primary hormone initiating CL regression in cattle [3]. Previous studies in cattle, pig, human and rat has indicated that PGF $2_{\alpha}$ activates ERK (extracellular-signal-regulated kinase) signaling in luteal cells $[5,6]$. PGF2 $\alpha$ binds to a G-protein coupled receptor on the target cell and activates PKC signaling pathway [7]. PKC further activates the MEK1/Raf/ERK1/2 signaling pathway in luteal cells $[5,8]$. Upon activation, ERK translocates to the nucleus where the binding of SRF/ Elk-1 is promoted which subsequently regulates EGR1 [9].

Early growth response (EGR) proteins are Cys2-His2type zinc-finger transcription factor family members. They are represented by the following genes: EGR1, EGR2, EGR3 and EGR4. EGR1, 2 and 3 are transcriptional activators whereas EGR4 is regarded as a transcriptional repressor [10]. EGR proteins specially bind to the major groove of DNA at GC-rich DNA recognition sites to alter the transcription of various genes necessary for differentiation and mitogenesis in the various tissues [11]. The best studied member of this family is EGR1. EGR1 is an $80-\mathrm{kDa}$ DNA binding protein which functions as a convergence point for many signaling cascades. Extracellular signaling from growth factors, hormones and cytokines induces EGR1 expression in a rapid and transitory manner [12]. Therefore, EGR1 gene is used for studying stimulus-transcription pairing [13].

EGR1 binds to regulatory regions of target genes. Indeed, EGR1 plays an essential role in the transcriptional regulation of genes whose protein products regulate CL regression [14]. One well described example is its ability to enhance transcription of transforming growth factor $\beta 1$ (TGF $\beta 1)[15,16]$. When bovine luteal cells are treated with luteolytic doses of $\mathrm{PGF} 2_{\alpha}$, the RAF/ERK/ MAPK kinase pathway is recognized as a primary signal, which induces EGR1 that leads to increase of TGF $\beta 1$ expression [17]. Expression of TGF $\beta 1$ is associated with $\mathrm{CL}$ regression through inhibition of luteal angiogenesis [18], increasing apoptosis, tissue remodeling [42] and suppression of progesterone production $[17,19]$. The expression of TGF $\beta 1$ in CL is up regulated when administered with PGF2 $\alpha$ during luteal regression $[5,17,20-22]$.

Previous studies, indicates that EGR1 plays an important role in PGF $2 \alpha$ induced expression of TGF $\beta 1$ which in turn plays an important role during luteal regression. However, studies on functional role of EGR1 on PGF2 $\alpha$ induced luteolysis in buffalo is not available. Hence, for the purpose, we knocked out (KO) the EGR1 gene via CRISPR/Cas 9 genome editing technology to examine how loss of EGR1 would influence TGF $\beta 1$ expression after PGF2 $\alpha$ treatment in luteal cells.

\section{Materials and methods}

All procedures and experimental protocols followed relevant safety guidelines and regulations.

\section{Collection of $\mathrm{CL}$}

Sixty ovaries from healthy buffalo cows with normal reproductive tracts to extract six CL per group for studies have been obtained from a local abattoir in $1 \times$ phosphate-buffered saline maintained at $37{ }^{\circ} \mathrm{C}$. Only mid-luteal stage corpus luteum was used in the present experiment. The selection of mid stage CL was conducted out as per our laboratory's pre-established protocol [23].

\section{Culture of luteal cells}

The luteal cells were cultured by using a pre-established protocol from our laboratory [24]. In brief, mid stage CLs were excised from the ovary and were chopped using BP blades (Bard-Parker Surgical Blade). The minced luteal tissue was washed thrice at $150 \times g$ for $5 \mathrm{~min}$ at room temperature with washing medium (Dulbecco's modified Eagle's medium DMEM/F12 medium (SH30023.01; Hyclone, Thermo Scientific) and 1\% antibiotic-antimycotic solution (Gibco; Thermo Scientific). After washing, the minced cells containing luteal, endothelial, pericytes and fibroblasts cells were digested in DMEM/ F12 medium containing collagenase $2 \mathrm{mg} / \mathrm{ml}$ (MP Biomedicals), DNaseI $25 \mathrm{mg} / \mathrm{ml}$ (MP Biomedicals) and 0.5\% bovine serum albumin (BSA). Washed cells were incubated in digestion media for 45 min twice in an orbital shaker incubator maintained at $37^{\circ} \mathrm{C}$. The digested cells were then filtered through a $70 \mu \mathrm{m}$ filter (Molsheim, France) and were washed in culture medium containing DMEM/F12 medium, 10\% fetal bovine serum (FBS; Sigma-Aldrich) and 1\% antibiotic-antimycotic solution. Cell viability was assessed by using Trypan blue vital staining (Sigma-Aldrich). Cells were then plated out at $1.5 \times 10^{5}$ viable cells per well in a 24-well plate with $1 \mathrm{~mL}$ culture medium and were maintained at $37{ }^{\circ} \mathrm{C}$ in a humidified $\mathrm{CO} 2(5 \%)$ incubator. Once plated, cells attached and grown until 75-80\% confluency (Fig. 1). 


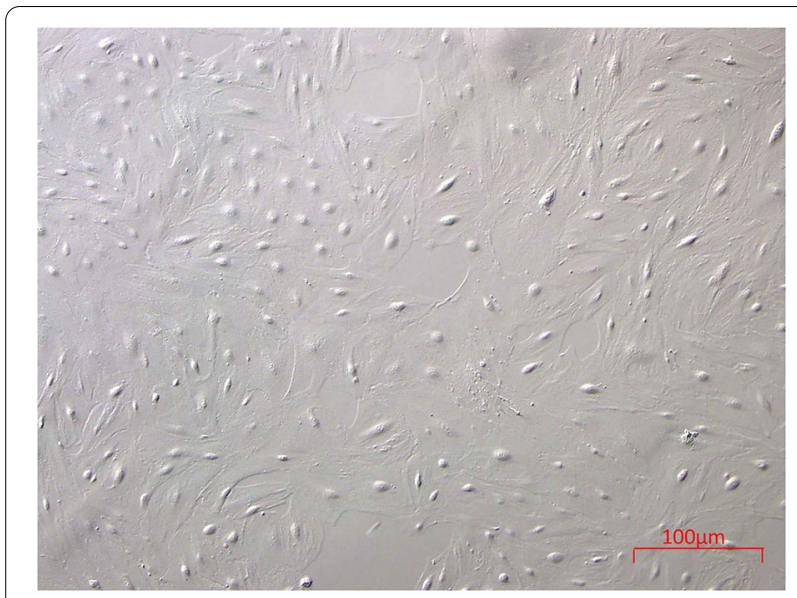

Fig. 1 Culture of attached luteal cells ( $\times 10$ magnification)

At this point, the medium was replaced with the fresh medium containing PGF2 $\alpha$ analog, $(0.1,1$ and $10 \mu \mathrm{g} / \mathrm{mL})$ [25]; cultures were maintained for $4,8,12 \mathrm{~h}$ in replicates of six each group. Control cells were grown in medium without hormone or growth factor. After the specified period of time, spent medium were collected and kept at $-20{ }^{\circ} \mathrm{C}$ until used for progesterone estimation by radioimmunoassay (RIA). Cells were trypsinized and total RNA was extracted via Qiazol (Qiagen).

\section{Production of EGR1 knock out (KO) luteal cells}

Production of EGR1 KO luteal cells was carried out by CRISPR/Cas9 by the method described earlier $[24,26]$. The CRISPR/Cas9 components (single guide RNA and Cas9) were delivered via lipofection into the luteal cells GeneArt Genomic Cleavage Detection Kit (Invitrogen) was used to validate the EGR1 KO and the cleavage efficiency was calculated by the following formula [27]: Cleavage efficiency $=[$ (sum of cleaved band intensities $) /$ (sum of cleaved and parental band intensities) $] \times 100 \%$

\section{Treatment of EGR1 KO luteal cells with PGF2a}

Following the above described procedure, all the EGR1 KO cells were cultured and grown until $75-80 \%$ confluency was reached. Thereafter, the medium was replaced with fresh medium with or without a PGF2 $\alpha$ analog $(10 \mu \mathrm{g} / \mathrm{mL})$. Cells were cultured for an additional $12 \mathrm{~h}$. Afterwards, the spent medium was collected and used for progesterone estimation. The cells were trypsined and total RNA was isolated.

\section{Primers}

The primers EGR1, AKT, Caspase3, StAR, TGF $\beta 1$, $3 \beta H S D, C Y P 11 A 1$ were designed using Gene Tool (online trial version), DNAStar (online trial version), and Oligo
Analyser (open access tool) software. For the study some published were used which includes $40 \mathrm{~S}$ ribosomal protein S15 (RPS15A) [24] and von willebrand factor $(v W F)$. In Table 1 is given the list of primers used for the analysis.

\section{Quantitative real time PCR analysis}

QIAzol reagent (QIAGEN) was used to extract total RNA from the cultured luteal cells. The purity of RNA was determined in Nanodrop spectrophotometer A260/ A280. The integrity of the total RNA was confirmed with electrophoresis of the agarose gel. Total RNA $(1 \mu \mathrm{g})$ was reversed transcribed to cDNA using a cDNA synthesis kit (ThermoFisher Scientific) as specified by the manufacturer using oligo $\mathrm{dT}$ primers at $42{ }^{\circ} \mathrm{C}$ for $60 \mathrm{~min}$. The qPCR was performed using the Maxima SYBR Green qPCR kit (Thermo Scientific). Each sample was run in triplicate in a $25 \mu \mathrm{L}$ reaction mixture consisting of $12.5 \mu \mathrm{L}$ SYBR green mix, $0.5 \mu \mathrm{L}$ each of $0.3 \mu \mathrm{M}$ forward and $0.3 \mu \mathrm{M}$ reverse primers, $1 \mu \mathrm{L}$ cDNA and $10.5 \mu \mathrm{L}$ nuclease-free water. The following general qPCR protocol was followed: initial denaturation for $10 \mathrm{~min}$ at $95^{\circ} \mathrm{C}$ followed by 40 denaturation cycles at $95^{\circ} \mathrm{C}$ for $15 \mathrm{~s}$, annealing and extension at $60{ }^{\circ} \mathrm{C}$ for $60 \mathrm{~s}$. Real-time PCR's efficiency was calculated by amplification of a standardized series of dilution, and slopes were achieved.

\section{Hormone determination}

The concentration of Progesterone (P4) in spent media of cultured luteal cell was assessed by P4 ${ }^{125}$ I RIA kit (Immunotech) according to the package recommendations. The coefficients of variation for intra and inter assay were $6.5 \%$ and $7.2 \%$ respectively.

\section{Statistical analysis}

All experimental data are shown as means. The software SPSS. 22 was used to determine the statistical significance of differences in transcriptional regulation of all genes and $\mathrm{P} 4$ concentrations (treatment dose and time interval) by two way analysis of variance followed by Tukey's honestly significant difference (HSD) test as a multiple comparison test. Differences were considered to be significant at $\mathrm{p}<0.05$.

\section{Results}

\section{Effects of Prostaglandin F2a on luteal cell steroidogenesis} in buffalo

To understand the effect of PGF2 $\alpha$ in corpus luteum, luteal cells derived from the mid stage CL of buffalo were treated with PGF2 $\alpha$. To determine the effect of PGF2 $\alpha$ on steroidogenesis, the progesterone concentration in the spent media and the relative expression of mRNAs encoding for enzymes within the progesterone biosynthetic pathway ( $3 \beta H S D, C Y P 11 A 1$ and StAR) were 
Table 1 Target gene, primer sequences and amplicon length used in the qPCR and Knockout study

\begin{tabular}{|c|c|c|c|}
\hline Gene & Sequences of nucleotide $\left(5^{\prime}-3^{\prime}\right)$ & Amplicon length (bp) & $\begin{array}{l}\text { EMBL accession } \\
\text { no. or reference }\end{array}$ \\
\hline EGR 1 & $\begin{array}{l}\text { Forward: AGCTGTGCAGTGCAGTCCAACGAC } \\
\text { Reverse: TAGTCGGGGATCATGGGAACCTG }\end{array}$ & 194 & XM_006070841.2 \\
\hline VWF & $\begin{array}{l}\text { Forward: ATCGTAGGGGACTTCCAAGGTGG } \\
\text { Reverse: CGGTCTCCAGGTATAGCCCTCTGG }\end{array}$ & 154 & 52 \\
\hline AKT & $\begin{array}{l}\text { Forward: AAACCGTTACCTTGCTATG } \\
\text { Reverse: TGCCCAGTTCGTTTCAGT }\end{array}$ & 159 & NM_174056.3 \\
\hline RPS15A & $\begin{array}{l}\text { Forward: AGGGCTGGGAAAATTGTTGTGAA } \\
\text { Reverse:TGAGGGGATGGGAGCAGGTTAT }\end{array}$ & 104 & 24 \\
\hline CYP11A1 & $\begin{array}{l}\text { Forward: AGACTTGGAGGGACCATGTAGC } \\
\text { Reverse: TGCCTGGGTAATTCCTAAATTC }\end{array}$ & 117 & XM_025271874.1 \\
\hline TGF $\beta 1$ & $\begin{array}{l}\text { Forward: AACAATTCCTGGCGCTACCTC } \\
\text { Reverse: TGCCGCACAACTCCAGTG }\end{array}$ & 92 & XM_006052063.2 \\
\hline $3 \beta H S D$ & $\begin{array}{l}\text { Forward: AATCCGGGTGCTAGACAAAGT } \\
\text { Reverse: CACTGCTCATCCAGAATGTCTC }\end{array}$ & 111 & XM_006049357.2 \\
\hline StAR & $\begin{array}{l}\text { Forward: CTGCGTGGATTAACCAGGTTCG } \\
\text { Reverse: CCAGCTCTTGGTCGCTGTAGAG }\end{array}$ & 84 & XM_006054485.2 \\
\hline EGR1 SgRNA & $\begin{array}{l}\text { Forward:TAATACGACTCACTATAGGTCCATGGTGGGCGAATG } \\
\text { Reverse: TTCTAGCTCTAAAACCATTCGCCCACCATGGAC }\end{array}$ & - & 26 \\
\hline EGR1 genomic detection & $\begin{array}{l}\text { EGR1 Forward: CTACCCCAGCCTCGGTAGCA } \\
\text { EGR1 Reverse: TCAGGTGCTCGTAGGGCTGC }\end{array}$ & & \\
\hline
\end{tabular}

analyzed. The study revealed a significant decrease in the progesterone concentration after $12 \mathrm{~h}$ of culture in a dose-dependent manner ( $\mathrm{p}<0.05$; Fig. $2 \mathrm{a}$ ). This finding was further supported by the study of mRNA expression of $3 \beta H S D, C Y P 11 A 1$ and StAR. Of the three concentrations tested, $10 \mu \mathrm{g} / \mathrm{mL}$ PGF2 $\alpha$ showed significant

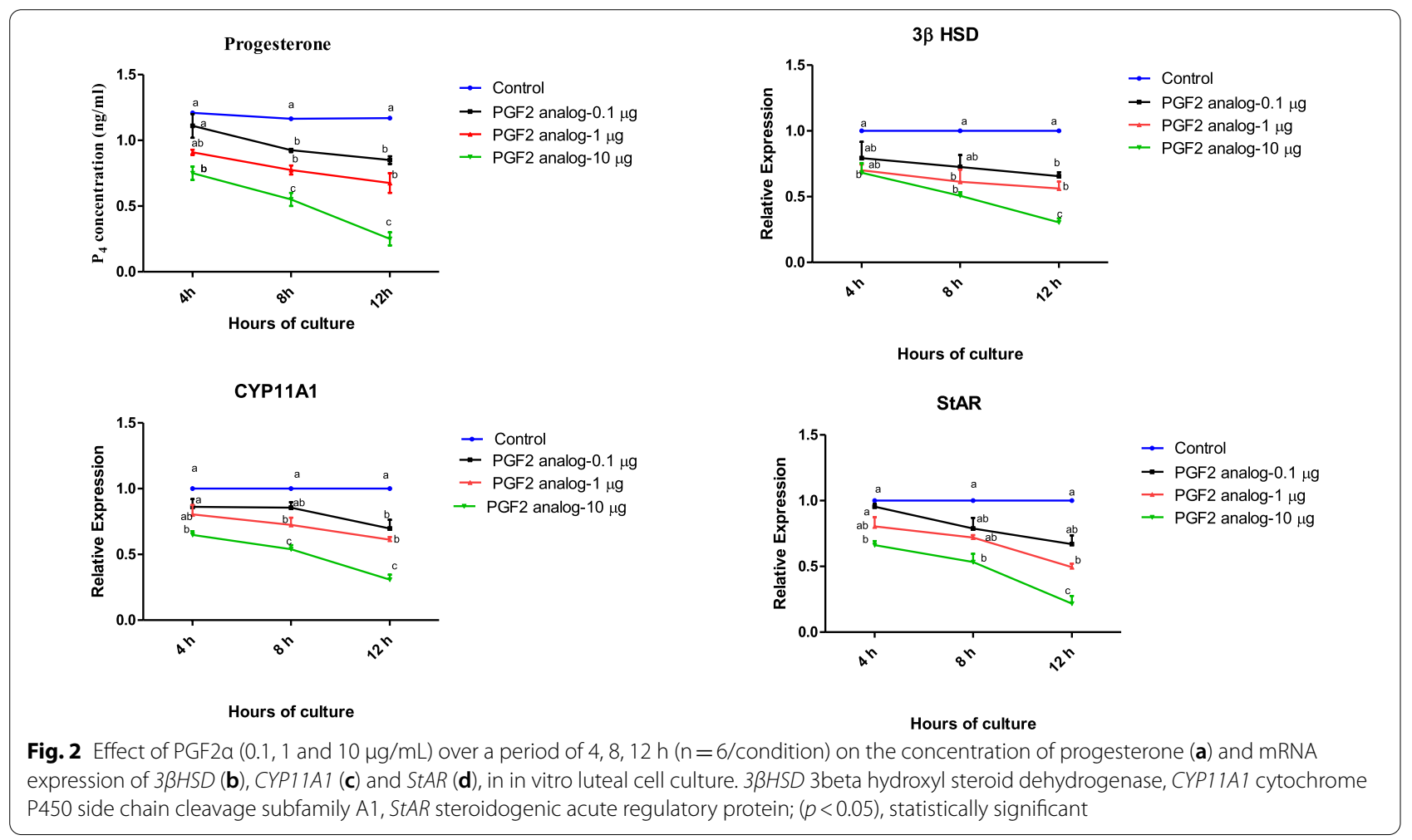


down regulation of progesterone biosynthetic pathway enzymes at $4,8,12 \mathrm{~h}$ of culture in comparison with the other doses $(\mathrm{p}<0.05$; Fig. $2 \mathrm{~b}-\mathrm{d})$.

\section{Effects of Prostaglandin F2 a on luteal cell viability and angiogenesis in buffalo}

In order to understand the effect of PGF $2 \alpha$ on luteal cell viability, mRNA expression of Caspase 3 and $A K T$ was studied. The mRNA expression study of apoptotic gene Caspase 3 was significantly up regulated in a time dependent manner at the highest dose of PGF2 $\alpha(\mathrm{p}<0.05$; Fig. 3a) as compared to other doses. However, the mRNA abundance of the cell proliferation gene, $A K T$, showed significant down regulation in all three doses of PGF $2 \alpha$ that were tested at 8 and $12 \mathrm{~h}(\mathrm{p}<0.05$; Fig. 3b). Similarly, the expression of the angiogenic marker, von Willebrand factor $(v W F)$, showed significant down regulation at $12 \mathrm{~h}$ of culture in all three doses of PGF $2 \alpha$ that were tested $(\mathrm{p}<0.05$; Fig. 3c).

\section{PGF2 $\alpha$ induces the expression of EGR1 and TGF $\beta 1$}

The present experiment determined whether EGR1 protein expression in luteal cells was responsive to PGF2 $\alpha$ treatment. The mRNA encoding for EGR1 significantly increased at the highest dose of PGF2 $\alpha(10 \mu \mathrm{g} / \mathrm{mL})$ in a time dependent manner $(\mathrm{p}<0.05$; Fig. $4 \mathrm{a})$ as compared

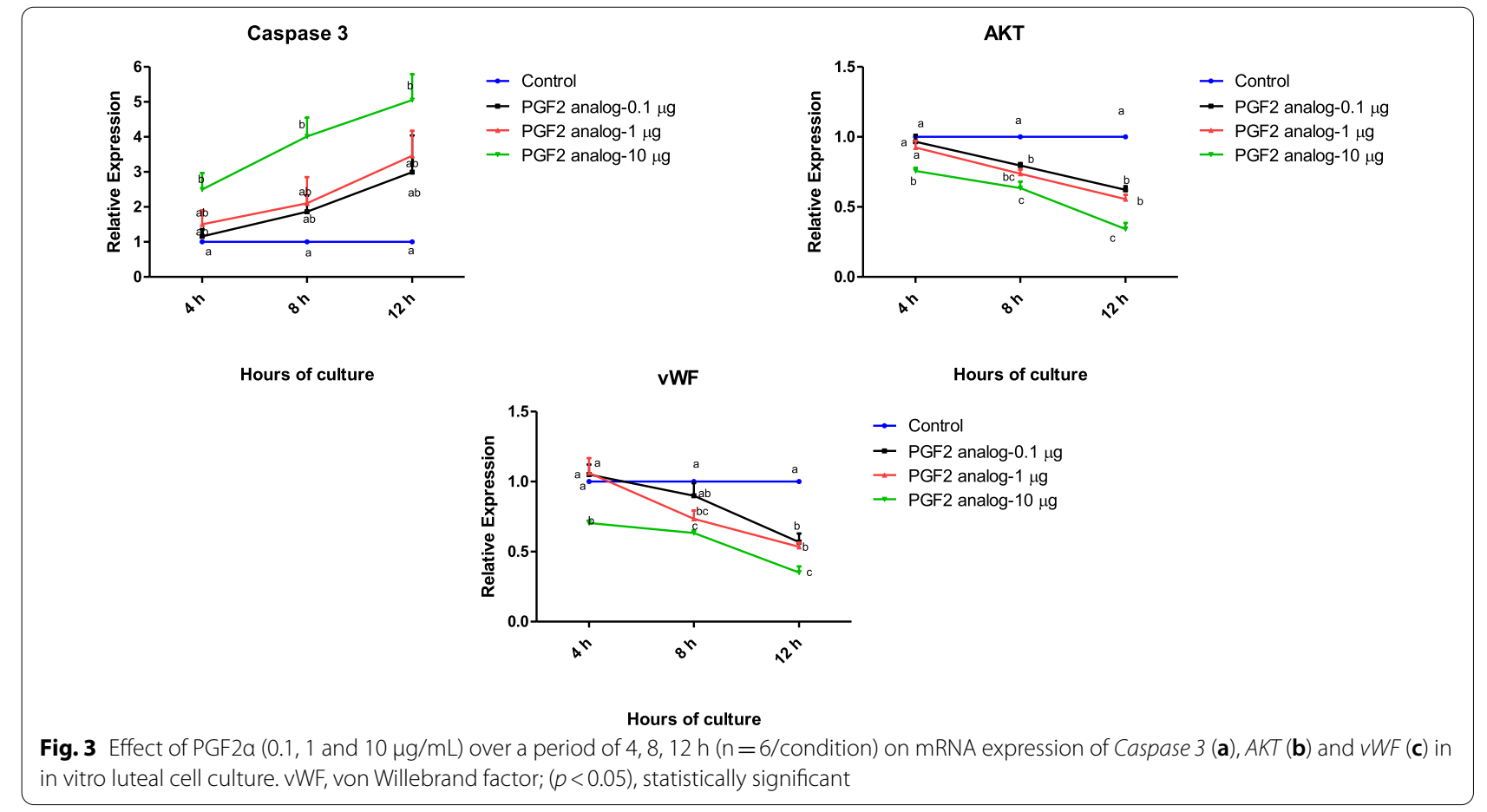

EGR1 mRNA

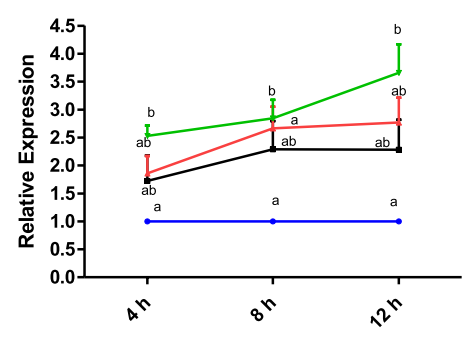

Hours of culture
TGF $\beta 1$ mRNA

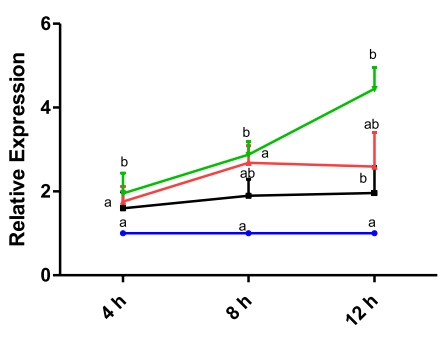

$\rightarrow$ Control

- PGF2 analog-0.1 $\mu \mathrm{g}$

- PGF2 analog-1 $\mu \mathrm{g}$

- PGF2 analog-10 $\mu \mathrm{g}$

- PGF2 analog-1 $\mu \mathrm{g}$

* PGF2 analog-10 $\mu \mathrm{g}$

Hours of culture

Fig. 4 Effect of PGF2a $(0.1,1$ and $10 \mu \mathrm{g} / \mathrm{mL})$ over a period of $4,8,12 \mathrm{~h}$ ( $\mathrm{n}=6 /$ condition) on $\mathrm{mRNA}$ expression of EGR1 (a) and TGF $\beta 1$ (b) in in vitro luteal cell culture. EGR1, Early Growth response factor 1; TGF $\beta 1$ transforming growth factor beta 1; $(p<0.05)$, statistically significant 
with the other doses. Similarly, the effect of PGF $2 \alpha$ at $10 \mu \mathrm{g} / \mathrm{mL}$ concentration also showed a significant increase in TGF $\beta 1$ mRNA at 4, 8, 12 h of culture as compared to other doses which did not show significant up regulation at 4 and $8 \mathrm{~h}$ of culture ( $\mathrm{p}<0.05$; Fig. $4 \mathrm{~b})$.

\section{Determining the effect of knocking out EGR1 on PGF2a induced expression of TGF $\beta 1$}

In order to validate the role of PGF $2 \alpha$ on stimulating the expression of TGF $\beta 1$ by an EGR1 dependent mechanism we knocked out EGR1 via CRISPR/Cas9 genome editing technology. The confirmation of EGR1 knock out was validated by T7E1 Genomic Cleavage Detection Kit, in which the efficiency of knock out of EGR1 was found to be $70 \%$ (Fig. 5). In the present study, we observed that PGF2 $\alpha$ induced TGF $\beta 1$ expression in EGR1 KO luteal cells. The ablation of EGR1 did not modulate the PGF $2 \alpha$ induced expression of TGF $\beta 1$ (Fig. 6).

\section{Determining the effect of knocking out EGR1 on PGF2a induced luteal cell viability and function}

The study revealed significant difference in the mRNA expression of Caspase 3 in EGR1 KO luteal cell and wild type luteal cells maintained for $12 \mathrm{~h}(\mathrm{p}<0.05$; Fig. 7a) in in vitro cell culture. In PGF2 $\alpha$ treated EGR1 KO luteal cells, the mRNA expression of Caspase 3 was significantly increased compared to PGF $2 \alpha$ treated wild type luteal cells maintained for $12 \mathrm{~h}$ ( $\mathrm{p}<0.05$; Fig. 7a). We also studied the influence of EGR1 on steroidogenesis and its

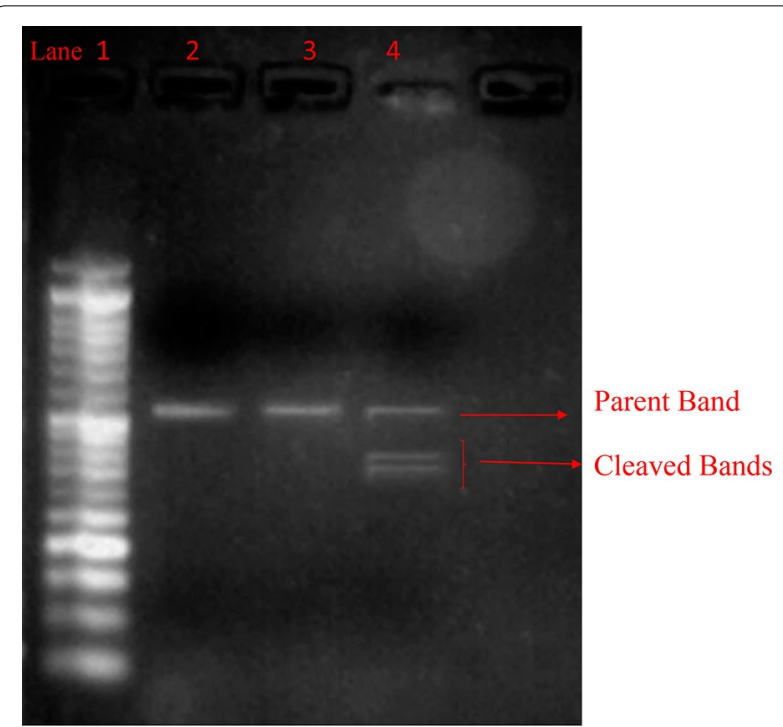

Fig. 5 Gel image of genomic cleavage detection assay of luteal cells transfected with Cas9 and EGR1 SgRNA using Lipofectamine 2000. Lane 1, 50 bp DNA ladder; Lane 2, negative control sample for EGR1 gene; Lane 3 sample without T7/E1 enzyme, Lane 4: sample, showing parent and both the cleaved bands after addition of T7/E1 enzyme

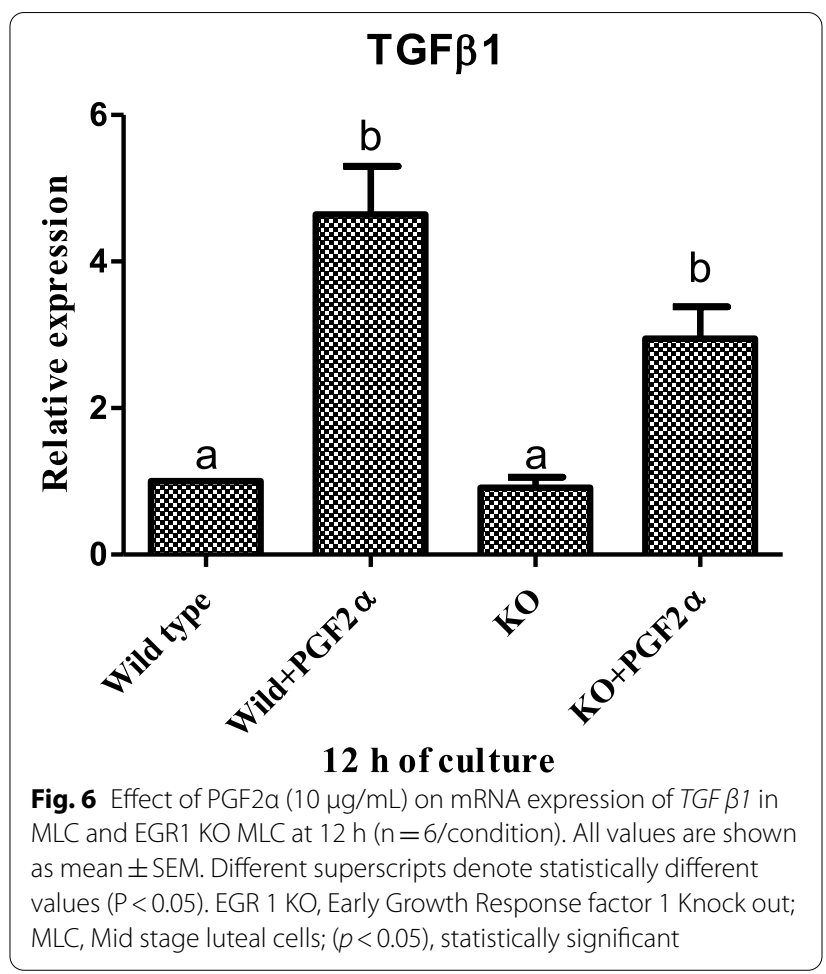

pathway. The progesterone concentration of EGR1 KO luteal cells in the spent media showed significant differences with the wild type luteal cells ( $\mathrm{p}<0.05$; Fig. $7 \mathrm{~b})$. The steroidogenic enzymes also showed significant difference between the wild type luteal cells and EGR1 KO luteal cells $(\mathrm{p}<0.05$; Fig. 7c). However, the EGR1 KO luteal cells with PGF $2 \alpha$ treatment showed no substantial difference either in the progesterone concentration or in StAR mRNA expression with PGF2 $\alpha$-treated wild type luteal cells (Fig. 7b, c).

\section{Discussion}

Dramatic morphological and functional changes occur during the life span of CL. In the absence of pregnancy, the mature CL eventually undergoes functional and structural regression, which is necessary for the initiation of a subsequent ovarian cycle. In cattle and related species, PGF $2 \alpha$ is the primary hormone initiating CL regression [3]. In fact, exogenous administration of PGF2 $\alpha$ can initiate luteolysis [28]. In buffalo, the functional phase of luteolysis lasts for approximately $12 \mathrm{~h}$ and is followed by structural changes in the luteal tissue; both of these changes are reflected by declining progesterone concentration in the blood [29]. In the present study, the progesterone concentration in the spent media was significantly down regulated upon treatment with PGF2 $\alpha(10 \mu \mathrm{g} /$ $\mathrm{mL}$ ) for 4,8 and $12 \mathrm{~h}$ duration (Fig. 2a). These findings are consistent with prior studies wherein progesterone 
Caspase 3
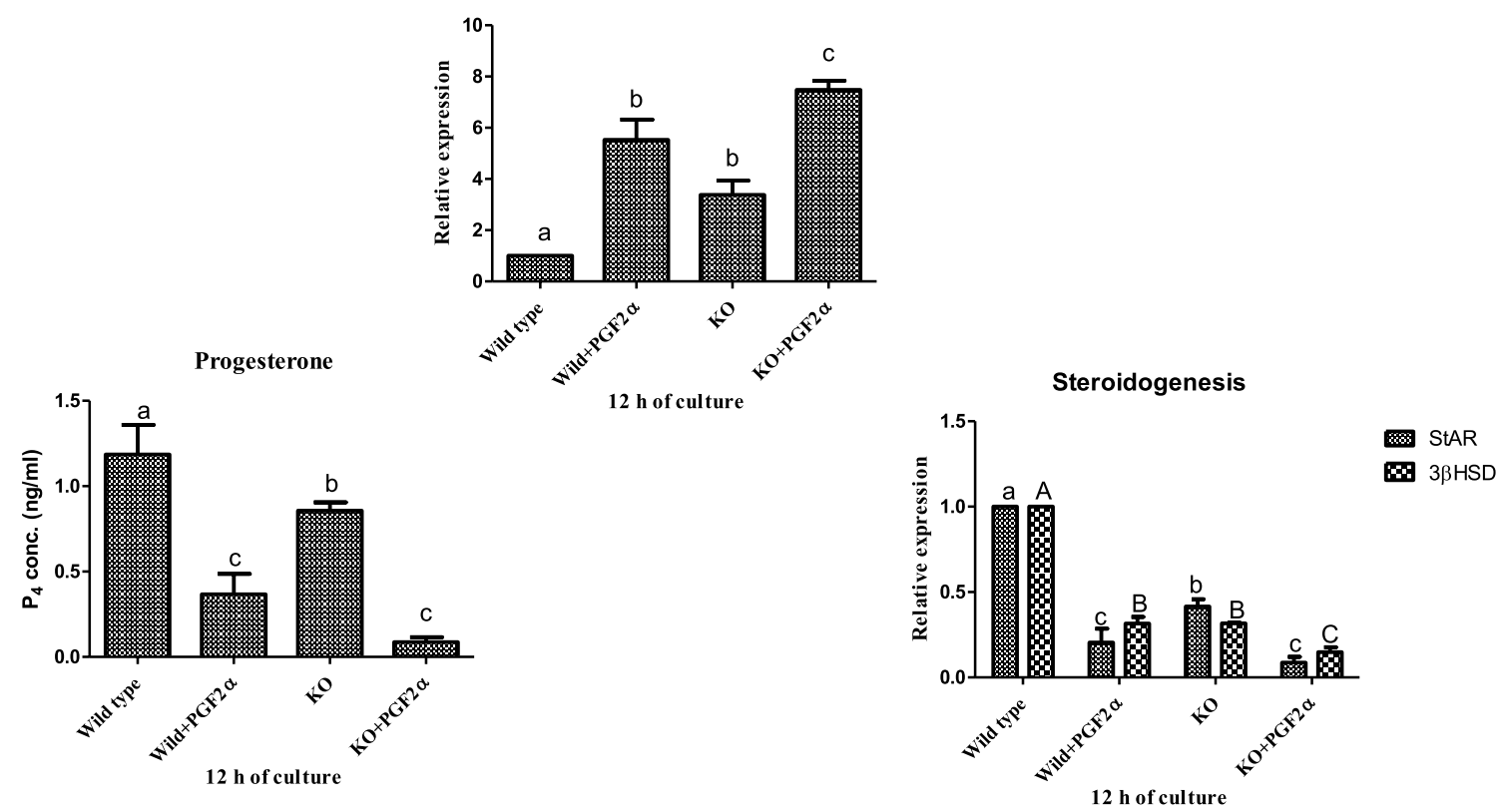

Fig. 7 Effect of PGF2a $(10 \mu \mathrm{g} / \mathrm{mL})$ on transcriptional abundance of Caspase 3 (a), Progesterone concentration (b) and on transcriptional abundance of StAR, 3BHSD (c) in MLC and EGR1 KO MLC at $12 \mathrm{~h}$ ( $\mathrm{n}=6 /$ condition). All values are shown as mean \pm SEM. Different superscripts denote statistically different values $(P<0.05)$. EGR1 KO Early Growth Response factor 1 Knock out, MLC mid stage luteal cells, StAR steroidogenic acute regulatory protein, 3BHSD 3beta hydroxyl steroid dehydrogenase; $(p<0.05)$, statistically significant

concentration decreased during the first $12 \mathrm{~h}$ after PGF2 $\alpha$ administration [4]. The decreased P4 production was also consistent with the observed mRNAs expression for 3BHSD, CYP11A1 and StAR (Fig. 2b-d). Once again, the results were in accordance with previous studies in which PGF $2 \alpha$ decreased progesterone concentration along with the down regulation of steroidogenic enzymes [2, 14]. PGF $2 \alpha$ administration produced a $30 \%$ decrease in plasma P4 concentration at $30 \mathrm{~min}$ and $2 \mathrm{~h}$ which further declined at $12 \mathrm{~h}$ [30]. Thus, the decrease in progesterone concentration in the spent media in our experiment confirmed the occurrence of luteolysis.

The structural involution of CL during its regression involves apoptosis, or cell programmed death $[6,31]$ which can be evaluated by the ratio of pro-apoptotic to anti apoptotic proteins [32]. The transcriptional abundance of Caspase 3 and $B A X$ within $C L$ are increased in buffalo CL treated with PGF2 $\alpha$, which is also correlated with declining progesterone [33]. In the present study, the expression of Caspase 3 increased, along with a decline in $A K T$ mRNA, in a dose and time dependent manner after PGF2 $\alpha$ treatment (Fig. 3a, b). We have demonstrated earlier that the effect of PGF2 $\alpha$ at $10 \mu \mathrm{g} /$ $\mathrm{mL}$ significantly up regulated the expression of Caspase 3 at $72 \mathrm{~h}$ of culture as compared to other doses at 24 and $48 \mathrm{~h} \mathrm{[25]}$ and it has also been reported that Caspase 3 is an essential mediator of apoptosis during luteolysis [34].
Thus, the increased expression of pro-apoptotic Caspase 3 during CL regression might be the ultimate reason for the disruption of steroidogenic cells which eventually leads to cell death.

Angiogenesis and vascularization of $\mathrm{CL}$ are required to supply nutrients and hormones for maintaining $\mathrm{CL}$ growth and survival [35]. Prostaglandin F2 $\alpha$ (PGF2 $\alpha)$ can inhibit angiogenesis to promote luteolysis [35]. Luteolysis is marked by a reduction in blood vessel density along with the degeneration and disappearance of luteal cells [36]. In the present study the angiogenic marker, vWF was significantly down regulated by PGF $2 \alpha$ treatment (Fig. 3c). The reduced angiogenesis could be due to reduced expression of the angiogenic growth factors, FGF2 and VEGF, and increased expression of anti-angiogenic factors, such as thrombospondin, which in turn destabilizes luteal vessel and reduces hormonal levels [37]. Most importantly, work earlier conducted in our laboratory shows that PGF2 $\alpha$ contributed to the luteolytic cascade by promoting the pro-apoptotic and anti angiogenic activity of Thrombospondin1 [25]. Other published reports have shown that the capillary degeneration and endothelial cell death are associated with PGF2 $\alpha$ induced luteolysis [38-41].

Transforming growth factor $\beta 1$ (TGF $\beta 1$ ) in luteal cell cultures is known for its potential involvement in apoptosis, tissue remodeling [42] and decreasing progesterone 
secretion [19]. The expression of TGF $\beta 1$ mRNA was found to be up regulated in CL when PGF2 $\alpha$ was administered to induce luteal regression in several species viz bovines [17, 20-22], mouse [43] etc. TGF $\beta 1$ facilitates luteal regression by disrupting the angiogenic potential of bovine microvascular endothelial cells [18]. In the present study, we have shown that a luteolytic dose of PGF2 $\alpha$ induced TGF $\beta 1$ mRNA in the buffalo luteal cells in vitro. Thus, PGF $2 \alpha$ plays a significant role in regulating the production of TGF $\beta 1$ during regression of the CL.

In the present investigation, EGR1 expression was found to be elevated in luteal cell when treated with PGF2 $\alpha$ in a dose dependent manner. In an earlier study conducted in bovines administration of PGF $2 \alpha$ increased EGR1 mRNA and EGR1 protein in CL [17]. During luteal regression in many species studied so far EGR1 plays a crucial role in the transcriptional regulation of genes [14]. EGR1 is a transcription factor that binds to the regulatory regions of many genes known to be involved in the regressive changes in CL during PGF2 $\alpha$ induced luteolysis; TGF $\beta 1$ is one of the regulated targets $[15,16]$. And this prompted us to validate the role of PGF $2 \alpha$ on stimulating the expression of TGF 1 by an EGR1 dependent mechanism and for this purpose EGR1 was knocked out via CRISPR/Cas9 genome editing technology. In our study, we observed that PGF2 $\alpha$ induces TGF $\beta 1$ expression in KO luteal cells and the ablation of EGR1 did not modulate the PGF2 $\alpha$ induced expression of TGF $\beta 1$. These finding suggests the presence of other signaling pathways that might be involved in PGF2 $\alpha$ induced TGF $\beta 1$ expression. PGF $2 \alpha$ when administered in luteal cells activates RAF/ERK/MAPK kinase pathway which subsequently up regulates EGR1 which in turn induces $T G F \beta 1$ expression [17]. In luteal cells, PGF2 $\alpha$ also in different signaling pathway stimulates thrombospondins 1 which activates TGF $\beta 1$ production [44]. In support of this, expression of TGF $\beta 1$ has been found to be reduced when TSP1 was silenced in bovine corpus luteum [45]. On the other hand, binding of PGF $2 \alpha$ to its receptor increases free intracellular calcium and also enhances the activity of mitogen-activated protein (MAP) kinase, phospholipase $\mathrm{C}$ and protein kinase $\mathrm{C}$ (PKC), with subsequent activation of multiple transcription factors [5, 46] including the ATF3, which plays an important role in the regulation of $\mathrm{CL}$ regression through production of TGF $\beta 1$, through a process independent of EGR1 in cattle [47]. In another study conducted in rats, the PGF activated JNK/SAPK signaling pathway stimulates the production of AP1 transcription factor that contribute to luteal regression via induction of chemokines including TGF $\beta 1$, also without the involvement of EGR1 [48]. These could be the plausible explanations why PGF2 $\alpha$ induced TGF $\beta 1$ production in our study was found to be dysregulated with EGR1 that is sharp contrast with the findings in cattle [17].

The present study also showed that the mRNA expression of Caspase 3 was significantly up regulated in EGR1 $\mathrm{KO}$ luteal cells, and PGF2 $\alpha$ treated KO luteal cells. Early growth response genes are important transcriptional regulators linked to cell proliferation and survival $[26,49$, 50]. The protein EGR1 directly or indirectly influences gene expression that is essential to cell proliferation [51]. Based on the cell environment and the primary stimuli employed, EGR1 has both pro-survival and pro-apoptotic activities [13]. The reduction in progesterone concentration in spent media in EGR1 KO luteal cells and PGF2 $\alpha$ treated EGR1 KO luteal cells in our study might be due to the increase apoptosis, reduction in the number of steroidogenic cells and a degeneration of the capillary network of the mature corpus luteum. Furthermore, significant up regulation of Caspase 3 and subdued progesterone production during in vitro treatment of EGR1 KO luteal cells with PGF2 $\alpha$ might be due to pronounced inhibition of EGR1 mediated luteal cell proliferation and migration. TGF $\beta 1$ production is known best for its potential involvement in apoptosis and tissue remodeling [42] and decreases progesterone secretion in luteal cell cultures [19]. Thus, the present study provides an important insight on functional role of EGR1 in Prostaglandin F2 alpha induced TGF $\beta 1$ expression during luteal regression in buffaloes.

\section{Conclusion}

The present study provided new insight into how the buffalo CL responds to PGF2 $\alpha$. It also illustrated some of the signaling pathways involved in regulating various functional and structural changes that occur during luteal regression. In our study, we have demonstrated that the luteolytic dose of PGF $2 \alpha$ induced TGF $\beta 1$ expression via EGR1 independent mechanism in buffalo. Despite the acquired expertise, much remains to be learned. Future studies elucidating the underlying mechanism of PGF $2 \alpha$ induced TGF $\beta 1$ expression during luteal regression will contribute to improve assisted reproductive technologies.

\section{Abbreviations \\ CL: Corpus Luteum; EGR: Early growth response; PGF2a: Prostaglandin F2 alpha; TGF $\beta 1$ : Transforming growth factor $\beta 1$. \\ Acknowledgements \\ We thank Director of Indian Veterinary Research Institute, Department of Biotechnology and Indo-US Science and Technology Forum for providing necessary facilities and funds for conducting this research work.}

\section{Authors' contributions}

MS involved in the design of the study, supplied reagents, conducted experiments, analyzed data, revised and edited manuscripts. MP conducted experiments, analyzed data, prepared the manuscript and figures. SK, AP, BJ, JB and AS analyzed data and reviewed the manuscript. JG and KW participated 
in designing the experiment, revised and edited manuscript. All authors reviewed the manuscript. All authors read and approved the final manuscript.

\section{Funding}

This study was supported by Indian Veterinary Research Institute, Department of Biotechnology and Indo-US Science and Technology Forum.

\section{Availability of data and materials}

All data generated or analysed during this study are included in this published article.

\section{Declarations}

\section{Ethics approval and consent to participate}

Not applicable.

\section{Consent for publication}

Not applicable.

\section{Competing interests}

The authors declare that they have no competing interests.

\section{Author details \\ 1 Physiology \& Climatology Division, ICAR-Indian Veterinary Research Institute, Izatnagar, Bareilly, Uttar Pradesh 243122, India. ${ }^{2}$ Animal Physiology, ICAR- National Research Centre on Pig, Guwahati, Assam, India. ${ }^{3}$ Division of Animal Genetics, ICAR-Indian Veterinary Research Institute, Izatnagar, Bareilly, Uttar Pradesh 243122, India. ${ }^{4}$ Division of Animal Science, University of Missouri- Columbia, Columbia, MO, USA.}

\section{Received: 21 August 2020 Accepted: 3 March 2021} Published online: 12 March 2021

\section{References}

1. Alila HW, Dowd JP, Corradino RA, Harris WV, Hansel W. Control of progesterone production in small and large bovine luteal cells separated by flow cytometry. JRI. 1988;82:645-55.

2. Tsai SJ, Wiltbank MC. Prostaglandin F2a regulates distinct physiological changes in early and mid-cycle bovine corpora lutea. Biol Reprod. 1998;58(2):346-52.

3. Niswender GD, Juengel JL, Silva PJ, Rollyson MK, Mclntush EW. Mechanisms controlling the function and life span of the corpus luteum. Physiol Rev. 2000;80(1):1-29.

4. Berisha B, Meyer HH, Schams D. Effect of prostaglandin F2 alpha on local luteotropic and angiogenic factors during induced functional luteolysis in the bovine corpus luteum. Biol Reprod. 2010;82(5):940-7.

5. Stocco CO, Lau LF, Gibori G. A calcium/calmodulin-dependent activation of ERK1/2 mediates JunD phosphorylation and induction of nur77 and 20a-hsd genes by prostaglandin F2a in ovarian cells. J Biol Chem. 2002;277(5):3293-302.

6. Davis JS, Rueda BR. The corpus luteum: an ovarian structure with maternal instincts and suicidal tendencies. Front Biosci. 2002;7:d1949-78.

7. Davis JS. Stimulation of intracellular free $\mathrm{Ca}^{2+}$ by luteinizing hormone in isolated bovine luteal cells. In: Regulation of ovarian and testicular function. Boston: Springer; 1987. p. 671-5.

8. Tai CJ, Kang SK, Choi KC, Tzeng CR, Leung PC. Role of mitogenactivated protein kinase in prostaglandin $\mathrm{F}(2 \mathrm{a})$ action in human granulosaluteal cells. J Clin Endocrinol Metab. 2001;86:375-80.

9. Pagel II, Deind I E. Early growth response 1-a transcription factor in the crossfire of signal transduction cascades. Indian J Biochem Biophys. 2011:48(4):226-35.

10. Liu D, Evans I, Britton G, Zachary I. The zinc-finger transcription factor, early growth response 3, mediates VEGF-induced angiogenesis. Oncogene. 2008;27(21):2989.

11. Thiel G, Müller I, Rössler OG. Expression, signaling and function of EGR transcription factors in pancreatic $\beta$-cells and insulin-responsive tissues. Mol Cell Endocrinol. 2014;388:10-9.
12. Zhang M, Liao Y, Lönnerdal B. EGR-1 is an active transcription factor in TGF- $\beta 2$-mediated small intestinal cell differentiation. J Nutr Biochem. 2016:37:101-8

13. Thiel $G$, Cibelli $G$. Regulation of life and death by the zinc finger transcription factor EGR -1. J Cell Physiol. 2002;193:287-92.

14. Atli MO, Bender RW, Mehta V, Bastos MR, Luo W, Vezina CM, Wiltbank MC. Patterns of gene expression in the bovine corpus luteum following repeated intrauterine infusions of low doses of prostaglandin F2alpha. Biol Reprod. 2012;86(4):130-1.

15. Kim SJ, Denhez F, Kim KY, Holt JT, Sporn MB, Roberts AB. Activation of the second promoter of the transforming growth factor 11 gene by transforming growth factor 11 and phorbol ester occurs through the same target sequences. J Biol Chem. 1989;264:19373-8.

16. Kim SJ, Glick A, Sporn MB, Roberts AB. Characterization of the promoter region of the human transforming growth factorß 1 gene. J Biol Chem. 1989;264:402-8

17. Hou X, Arvisais EW, Jiang C, Chen DB, Roy SK, Pate JL, Hansen TR, Rueda BR, Davis JS. Prostaglandin F2a stimulates the expression and secretion of transforming growth factor B1 via induction of the early growth response 1 gene (EGR1) in the bovine corpus luteum. Mol Endocrinol. 2008;22(2):403-14

18. Maroni D, Davis JS. TGFB1 disrupts the angiogenic potential of microvascular endothelial cells of the corpus luteum. J Cell Sci. 2011;124(14):2501-10

19. Miyamoto A, Okuda K, Schweigert FJ, Schams D. Effects of basic fibroblast growth factor, transforming growth factor-8 and nerve growth factor on the secretory function of the bovine corpus luteum in vitro. Endocrinology. 1992;135:I03-114

20. Davis JS, May JV, Keel BA. Secretion of TGFI3I by luteal cells: regulation by PGF and mediation by protein kinase $C$ and mitogen-activated protein (MAP) kinase. Biol Reprod. 1995:52(Suppl I):96abstr.

21. Mondal M, Schilling B, Folger J, Steibel JP, Buchnick H, Zalman Y, Ireland JJ, Meidan R, Smith GW. Deciphering the luteal transcriptome: potential mechanisms mediating stage-specific luteolytic response of the corpus luteum to prostaglandin F2a. Physiol Genom. 2011;43(8):447-56.

22. Shah D, Mahajan N, Sah S, Nath SK, Paudyal B. Oxidative stress and its biomarkers in systemic lupus erythematosus. J Biomed Sci. 2014;21(1):23.

23. Sarkar M, Schilffarth S, Schams D, Meyer HH, Berisha B. The expression of leptin and its receptor during different physiological stages in the bovine ovary. Mol Reprod Dev Incorp Gamete Res. 2010;77(2):174-81.

24. Paul A, Punetha M, Kumar S, Sonwane A, Chouhan VS, Singh G, Maurya VP, Sarkar M. Regulation of steroidogenic function of luteal cells by thrombospondin and insulin in water buffalo (Bubalus bubalis). Reprod Fertil Dev. 2018:31(4):751-9.

25. Paul A, Bharati J, Punetha M, Kumar S, Vidyalakshmi GM, Chouhan VS, Sonwane A, Bhure S, Maurya VP, Singh G, Whitworth KM, Sarkar M. Transcriptional regulation of thrombospondins and its functional validation through CRISPR/Cas9 mediated gene editing in corpus luteum of water buffalo (Bubalus bubalis). Cell Physiol Biochem. 2019:52(3):532-52.

26. Punetha M, Chouhan VS, Arvind S, Singh G, Sadhan B, Green JA, Whitworth $\mathrm{K}$, Sarkar M. Early growth response gene mediates in VEGF and FGF signaling as dissected by CRISPR in corpus luteum of water buffalo. Sci Rep. 2020;10(1):1-12.

27. Liang X, Potter J, Kumar S, Zou Y, Quintanilla R, Sridharan M, Carte J, Chen W, Roark N, Ranganathan S, Ravinder N. Rapid and highly efficient mammalian cell engineering via Cas9 protein transfection. J Biotechnol. 2015;208:44-53.

28. McCracken JA, Custer EE, Lamsa JC. Luteolysis: a neuroendocrine-mediated event. Physiol Rev. 1999;79(2):263-323.

29. Niswender GD, Juengel JL, McGuire WJ, Belfiore CJ, Wiltbank MC Luteal function: the estrous cycle and early pregnancy. Biol Reprod. 1994:50(2):239-47.

30. Shirasuna K, Jiemtaweeboon S, Raddatz S, Nitta A, Schuberth HJ, Bollwein $\mathrm{H}$, Shimizu T, Miyamoto A. Rapid accumulation of polymorphonuclear neutrophils in the corpus luteum during prostaglandin F2a-induced luteolysis in the cow. PLOS ONE. 2012;7(1):e29054.

31. Korzekwa AJ, Shuko M, Jaroszewski J, Wocławek-Potocka I, Okuda K Skarzynski DJ. Nitric oxide induces programmed cell dead in the bovine corpus luteum: mechanism of action. J Reprod Dev. 2006;52:353-61. 
32. Anderson LE, Wu YL, Tsai SJ, Wiltbank MC. Prostaglandin F2a receptor in the corpus luteum: recent information on the gene, messenger ribonucleic acid, and protein. Biol Reprod. 2001;64(4):1041-7.

33. Yadav VK, Sudhagar RR, Medhamurthy R. Apoptosis during spontaneous and prostaglandin F2a-induced luteal regression in the buffalo cow (Bubalus bubalis): involvement of mitogen-activated protein kinases. Bio Reprod. 2002;67(3):752-9.

34. Carambula SF, Matikainen T, Lynch MP, Flavell RA, Dias Gonçalves PB, Tilly $J$, Rueda BR. Caspase-3 is a pivotal mediator of apoptosis during regression of the ovarian corpus luteum. Endocrinology. 2002;143(4):1495-501.

35. Skarzynski DJ, Piotrowska-Tomala KK, Lukasik K, Galvao A, Farberov S, Zalman Y, Meidan R. Growth and regression in bovine corpora lutea: regulation by local survival and death pathways. Reprod Domest Anim. 2013;48:25-37.

36. Augustin HG, Braun K, Telemenakis I, Modlich U, Kuhn W. Ovarian angiogenesis. Phenotypic characterization of endothelial cells in a physiological model of blood vessel growth and regression. Am J Pathol. 1995;147(2):339.

37. Zalman Y, Klipper E, Farberov S, Mondal M, Wee G, Folger JK, Smith GW, Meidan R. Regulation of angiogenesis-related prostaglandin f2alpha-induced genes in the bovine corpus luteum. Biol Reprod. 2012;86(3):92-101.

38. Azmi TI, O'shea JD. Mechanism of deletion of endothelial cells during regression of the corpus luteum. Lab Investig. 1984;51(2):206-17.

39. Rueda BR, Tilly KI, Hansen TR, Hoyer PB, Tilly JL. Expression of superoxide dismutase, catalase and glutathione peroxidase in the bovine corpus luteum: evidence supporting a role for oxidative stress in luteolysis. Endocrine. 1995;3(3):227-32.

40. Bacci ML, Barazzoni AM, Forni M, Costerbosa GL. In situ detection of apoptosis in regressing corpus luteum of pregnant sow: evidence of an early presence of DNA fragmentation. Domest Anim Endocrinol. 1996;13(4):361-72.

41. Gaytan F, Morales C, Garcia-Pardo L, Reymundo C, Bellido C, SanchezCriado JE. A quantitative study of changes in the human corpus luteum microvasculature during the menstrual cycle. Biol Reprod. 1999;60(4):914-9.

42. Roberts AB, Kim SJ, Kondaiah P, Jakowlew SB, Denhez F, Glick AB, Sporn MB. Transcriptional control of expression of the TGF- $\beta$ s. Ann NY Acad Sci. 1990;593(1):43-50.

43. Wang Z, Tamura K, Yoshie M, Tamura H, Imakawa K, Kogo H. Prostaglandin F2ainducedfunctional regression of the corpus luteum and apoptosis in rodents. J Pharmacol Sci. 2003;92:19-27.
44. Murphy-Ullrich JE, Poczatek M. Activation of latent TGF- $\beta$ by thrombospondin-1: mechanisms and physiology. Cytokine Growth Factor Rev. 2000;11(1-2):59-69.

45. Farberov S, Klipper E, Meidan R. Mechanisms underlying thrombospondin-1 actions in ovarian granulosa and endothelial cells. Biol Reprod. 2012;87(Suppl_1):47.

46. Chen D, Fong HW, Davis JS. Induction of c-fos and c-jun messenger ribonucleic acid expression by prostaglandin F2a is mediated by a protein kinase C-dependent extracellular signal-regulated kinase mitogenactivated protein kinase pathway in bovine luteal cells. Endocrinology. 2002;142(2):887-95.

47. Mao D, Hou X, Talbott H, Cushman R, Cupp A, Davis JS. ATF3 expression in the corpus luteum: possible role in luteal regression. Mol Endocrinol. 2013:27(12):2066-79.

48. Talbott H, Hou X, Qiu F, Zhang P, Guda C, Yu F, Cushman RA, Wood JR, Wang C, Cupp AS, Davis JS. Early transcriptome responses of the bovine midcycle corpus luteum to prostaglandin F2a includes cytokine signaling. Mol Cell Endocrinol. 2017:452:93-109.

49. Khachigian LM, Collins T. Inducible expression of Egr-1-dependent genes: a paradigm of transcriptional activation in vascular endothelium. Circ Res. 1997;81(4):457-61.

50. Hallahan DE, Dunphy E, Virudachalam S, Sukhatme VP, Kufe DW, Weichselbaum RR. C-jun and Egr-1 participate in DNA synthesis and cell survival in response to ionizing radiation exposure. J Biol Chem. 1995;270(51):30303-9.

51. Krones-Herzig A, Mittal S, Yule K, Liang H, English C, Urcis R, Soni T, Adamson ED, Mercola D. Early growth response 1 acts as a tumor suppressor in vivo and in vitro via regulation of p53. Cancer Res. 2005:65(12):5133-43.

52. Rajesh G, Paul A, Mishra SR, Bharati J, Thakur N, Mondal T, Soren S, Harikumar S, Narayanan K, Chouhan VS, Bag S, Das BC, Singh G, Maurya VP, Sharma Taru G, Sarkar M. Expression and functional role of bone morphogenetic proteins (BMPs) in cyclical corpus luteum in buffalo (Bubalus bubalis). Gen Comp Endocr. 2017;240:198-213.

\section{Publisher's Note}

Springer Nature remains neutral with regard to jurisdictional claims in published maps and institutional affiliations.
Ready to submit your research? Choose BMC and benefit from:

- fast, convenient online submission

- thorough peer review by experienced researchers in your field

- rapid publication on acceptance

- support for research data, including large and complex data types

- gold Open Access which fosters wider collaboration and increased citations

- maximum visibility for your research: over $100 \mathrm{M}$ website views per year

At BMC, research is always in progress.

Learn more biomedcentral.com/submissions 